\begin{tabular}{lr}
\hline \multicolumn{1}{c}{ D Y N A M I C E C O N O M E T R I C } & M O D E L S \\
DOI: http://dx.doi.org/10.12775/DEM.2018.004 & Vol. 18 (2018) 67-79 \\
\hline $\begin{array}{l}\text { Submitted November 23, 2018 } \\
\text { Accepted December 19,2018 }\end{array}$ & ISSN (online) 2450-7067 \\
ISSN (print) 1234-3862
\end{tabular}

\title{
Joanna Olbryś@*
}

\section{The Non-Trading Problem in Assessing Commonality in Liquidity on Emerging Stock Markets**}

\begin{abstract}
A b s t r a ct. The purpose of this study is to explore commonality in liquidity on seven small emerging CEE stock markets in the Czech Republic, Hungary, Slovakia, Slovenia, Lithuania, Estonia, and Latvia, in the context of serious problems with stock illiquidity. The number of companies that reveal a substantial non-trading problem is large. A modified version of the Amihud measure is utilized as daily liquidity proxy for stocks. The OLS-HAC method and the GARCH-type models are employed to infer the patterns of commonality in liquidity. No reason has been found to support intra-market commonality in liquidity on each investigated stock exchange.
\end{abstract}

K e y w o r d s: CEE; commonality in liquidity; GARCH; HAC; non-trading problem.

J E L Classification: C32; C58; G15; O57.

\section{Introduction}

Investors prefer assets that are liquid, therefore stock market liquidity is of important concern to many investors. Commonality in liquidity means that financial asset liquidity changes over time, and that these time variations are ruled by a significant common component in the liquidity across assets or market liquidity. The existence of commonality suggests the assumption that there exists at least one common factor that simultaneously influences liquidity of all stocks in a market.

\footnotetext{
* Correspondence to: Joanna Olbryś, Bialystok University of Technology, Faculty of Computer Science, 45A Wiejska Street, 15-351 Białystok, Poland, e-mail: j.olbrys@pb.edu.pl.

${ }^{* *}$ This work was financed by the grant from the National Science Centre, Poland, No. 2016/21/B/HS4/02004.

(C) 2018 Nicolaus Copernicus University. All rights reserved. http://www.dem.umk.pl/dem
} 
Chordia et al. (2000) have been the first that analysed commonality in liquidity on a stock exchange. The authors explored the U.S. market and the literature concerning commonality in liquidity for the U.S. stock market has emerged in the last years, e.g (Kamara et al., 2008; Korajczyk and Sadka, 2008; Kang and Zhang, 2013).

Commonality in liquidity has been investigated for other individual equity markets in the world. Among others, Brockman and Chung (2006) explored the Stock Exchange of Hong Kong, Fabre and Frino (2004) studied the Australian Stock Exchange, Kempf and Mayston (2008) analysed the Frankfurt Stock Exchange, Pukthuanthong-Le and Visaltanachoti (2009) assessed the Stock Exchange in Thailand, Foran et al. (2015) examined the London Stock Exchange, Narayan et al. (2015) tested the Chinese stock exchanges (in Shanghai and Shenzhen), Miralles Marcelo et al. (2015) studied the Euronext Lisbon Stock Exchange, Sensoy (2016) investigated the Turkish stock market, Syamala et al. (2017) analysed the Indian stock market, and Olbryś (2018) explored the Polish stock exchange in Warsaw. In general, the empirical results on different stock markets in the world are not homogeneous.

A number of studies that concern commonality in liquidity for a group of international financial markets is rather limited. For example, Brockman et al. (2009) applied methodology of Chordia et al. (2000) to examine commonality in liquidity on 47 stock exchanges. They documented the pervasive role of commonality in liquidity within individual exchanges and they found evidence of a distinct, global component in bid/ask spreads and depths across exchanges. Karolyi et al. (2012) explored cross-country commonality in liquidity using daily data for individual stocks from 40 developed and emerging countries. Wang (2013) investigated the impact of a set of common factors on liquidity variations in 12 Asian equity markets. Bai and Qin (2015) analysed commonality in liquidity on 18 emerging markets. The authors pointed out that liquidity co-movements across emerging markets have a strong geographic component.

Among others, Bekaert et al. (2007) stress that liquidity is more critical for emerging than developed markets. Moreover, it is a well-known fact that a non-trading effect induces potentially serious biases in various statistical measures of asset returns (e.g. Nowak and Olbryś, 2016). We refer to nontrading as a lack of transactions over a particular period when a stock exchange is open for trading. The lack of transactions means that the volume (in items) is equal to zero. Empirical analyses of a number of zeros in daily volume for companies listed on seven small CEE stock exchanges in the Czech Republic, Hungary, Slovakia, Slovenia, Lithuania, Estonia, and Latvia reveal that the non-trading problem is crucial on these markets. Therefore, in this paper we analyse intra-market liquidity co-movements in the context of 
problems with asset illiquidity. The research hypothesis that there is no commonality in liquidity on each investigated CEE stock market, taken separately, is tested. A modified version of the Amihud (2002) measure is used as daily liquidity proxy, in the period from January 2, 2012 to December 30, 2016. We utilize the research design of Chordia et al. (2000), but we employ the OLSHAC method (Newey and West, 1987) and the GARCH-type models (if necessary) to infer the patterns of commonality in liquidity. In the market models of liquidity, positive and statistically significant slope coefficients are especially desired, because they indicate intra-market co-movements in liquidity in the same direction, and therefore confirm commonality in liquidity. However, the regressions provide no evidence of commonality in liquidity on the CEE stock markets because positive and statistically significant coefficients are scarce. Therefore, no reason has been found to support commonality in liquidity on each investigated stock exchange. The empirical findings are homogeneous for all investigated markets.

To the best of the author's knowledge, the results concerning commonality in liquidity on the CEE stock exchanges in the context of non-trading problems are novel and have not been presented in the literature thus far.

The remainder of the study is organized as follows. Section 1 specifies the methodological background concerning the measurement of commonality in liquidity. Section 2 describes the data and discusses serious problems in illiquidity on the CEE emerging stock markets. Section 3 presents some empirical results of testing for commonality in liquidity on the investigated markets. Conclusion covers the main findings.

Table 1. Nomenclature

\begin{tabular}{cc}
\hline PSE & Prague Stock Exchange (the Czech Republic) \\
BSE & Budapest Stock Exchange (Hungary) \\
BSSE & Bratislava Stock Exchange (Slovakia) \\
LJSE & Ljubljana Stock Exchange (Slovenia) \\
NASDAQ Vilnius & Stock Exchange in Vilnius (Lithuania) \\
NASDAQ Tallinn & Stock Exchange in Tallinn (Estonia) \\
NASDAQ Riga & Stock Exchange in Riga (Latvia) \\
\hline
\end{tabular}

\section{Assessing Commonality in Liquidity}

The literature contains a number of methods for assessing commonality in liquidity. To identify common determinants of liquidity, the classical market model of liquidity, introduced by Chordia et al. (2000) has been most frequently used. In this research, the modified version of classical market model of liquidity, including the Dimson (1979) correction for daily data is applied:

$$
D L_{i, t}=\alpha_{i}+\beta_{i,-1} D L_{M, t-1}+\beta_{i, 0} D L_{M, t}+\beta_{i,+1} D L_{M, t+1}+\varepsilon_{i, t},
$$


where $D L_{i, t}$ for stock $i$ is the change in liquidity variable $L$ from trading day $t-1$ to $t$, i.e. $D L_{t}=\frac{L_{t}-L_{t-1}}{L_{t-1}}$.

According to the Dimson procedure, the $D L_{M, t-1}, D L_{M, t}$, and $D L_{M, t+1}$ are the lagged, concurrent, and leading changes is a cross-sectional average of the liquidity variable $L$, respectively. The Dimson correction enables us to accommodate the problem of nonsynchronous trading effects (Campbell et al., 1997).

In computing the 'market' liquidity proxy $L_{M}$, stock $i$ is excluded, so the explanatory variables in model (1) are slightly different for each stock's time series regression. Chordia et al. (2000) stress that changes are examined rather than levels because the interest is fundamentally in discovering whether liquidity moves. Based on model (1), positive and statistically significant slope coefficients are especially desired, as they indicate intra-market co-movements in liquidity and therefore confirm commonality in liquidity. In other words, they inform about liquidity co-movements in the same direction.

In this study, a modified version of the Amihud (2002) measure, $M A m i h_{i, d}$ given by Eq. (2), is utilized as liquidity/illiquidity proxy:

$$
\operatorname{MAmih}_{i, d}=\left\{\begin{array}{c}
\log \left(1+\frac{\left|r_{i, d}\right|}{V_{i, d}}\right), \text { when } V_{i, d} \neq 0 \\
0, \text { when } V_{i, d}=0
\end{array},\right.
$$

where:

$r_{i, d}$ is the simple rate of return of stock $i$ on day $d$,

$V_{i, d}$ is the trading volume of stock $i$ on day $d$.

We follow Karolyi et al. (2012), but our method is slightly different, because they use return and volume in local currency, and finally multiply the result by negative one to obtain a variable that is increasing alongside with liquidity of individual stock. Moreover, the value of daily Amihud measure (2) is defined to be equal to zero when the total volume of daily trading, in the denominator, is equal to zero. The second condition in definition (2) is consistent with analogous conditions for other daily liquidity/illiquidity proxies (Olbrys and Mursztyn, 2018). Furthermore, to avoid numerical problems, the daily values of the estimator (2) are rescaled by multiplying by $10^{2}$. In the literature, the Amihud measure is usually calculated for stock $i$ for each month, e.g. (Goyenko et al., 2009; Olbryś, 2014; Foran et al., 2015; Fong et al., 2017; Będowska-Sójka, 2018). In this paper, we estimate daily time series of the Amihud proxy (2).

For each stock, the model (1) is initially estimated by using the OLS method and the robust HAC estimates (Newey and West, 1997). However, the Newey and West method may not fully correct for the influence problems 
introduced by the ARCH effect. For this reason, the estimation of the model (1) as a GARCH-type model is appropriate. To test for the ARCH effect, the test of Engle (1982) with the Lagrange Multiplier (LM) statistic is employed. In this research, the $\operatorname{GARCH}(p, q)$ model is utilized. According to the literature, the lower order $\operatorname{GARCH}(p, q), p, q=1,2$, models are used in most applications (Tsay, 2010). The GARCH $(p, q)$ models are compared and selected by the Akaike (AIC) and Schwarz (SC) information criteria.

The GARCH(p, q) model is given by Eq. (3):

$$
\begin{gathered}
D L_{i, t}=\alpha_{i}+\beta_{i,-1} D L_{M, t-1}+\beta_{i, 0} D L_{M, t}+\beta_{i,+1} D L_{M, t+1}+\varepsilon_{i, t}, \\
\varepsilon_{i, t}=z_{i, t} \sqrt{\mathrm{h}_{i, t}}, z_{i, t} \sim N(0,1) \\
\mathrm{h}_{\mathrm{i}, \mathrm{t}}=a_{i, 0}+\sum_{k=1}^{q} a_{i, k} \varepsilon_{i, t-k}^{2}+\sum_{l=1}^{p} b_{i, l} \mathrm{~h}_{\mathrm{i}, \mathrm{t}-1}
\end{gathered}
$$

where:

$a_{i, 0}>0, a_{i, k} \geq 0, k=1, \ldots, q, q>0, b_{i, l} \geq 0, l=, \ldots, p, p \geq 0$,

$\varepsilon_{i, t}$ is the innovation in a linear regression with $V(\varepsilon)=\sigma^{2}$,

$h_{i, t}$ is the variance function,

and remaining notation like in Eq. (1).

The parameters of $\operatorname{GARCH}(p, q)$ models are almost invariably estimated via Maximum Likelihood (ML) or Quasi-Maximum Likelihood (QML) (Bollerslev and Wooldridge, 1992) methods, which bring up the subject of a suitable choice for the conditional distribution of innovation. Our primary interest is the estimating the conditional mean equation, but Hamilton (2008) stresses that having a correct description of the conditional variance can still be quite important. By incorporating the observed features of the heteroskedasticity into the estimation of the conditional mean, substantially more efficient estimates of the conditional mean can be obtained.

\section{Data Description and Serious Problems with Asset Illiquidity}

In this research, daily data for seven small emerging stock markets from the Central and Eastern European countries, namely the Czech Republic, Hungary, Slovakia, Slovenia, Lithuania, Estonia, and Latvia, are used. Data is coming from Bloomberg under the license agreement between Bloomberg and Bialystok University of Technology (the grant No. 2016/21/B/HS4/ 02004). The data set contains the opening, high, low, and closing prices, as well as volume for a security over each trading day, in the period from January 2, 2012 to December 30, 2016. Specifically, the database holds 1252 (for the PSE), 1240 (for the BSE), 1244 (for the BSSE), 1245 (for the LJSE), 1245 (for the NASDAQ Vilnius), 1251 (for the NASDAQ Tallinn), and 1242 (for the NASDAQ Riga) trading days, respectively. The Warsaw Stock Exchange (WSE) is not included in the research because it is large compared to the other 
CEE stock exchanges. For comparison, at the end of 2016 the total number of listed stocks was equal to: 881 (WSE), 23 (PSE), 41 (BSE), 71 (BSSE), 37 (LJSE), 34 (NASDAQ Vilnius), 17 (NASDAQ Tallinn), and 32 (NASDAQ Riga).

It is commonly known fact that a large number of the CEE stock markets listed companies reveal a substantial non-trading problem. Therefore, to mitigate this problem, we excluded the stocks that exhibited extraordinarily many non-traded days during the whole sample period. Specifically, because the analysed CEE stock markets were extremely illiquid, the basic condition concerning the maximum number of non-traded days for these markets was equal to 373 , which constituted about $30 \%$ of all trading days.

Table 2. Serious problems with stock illiquidity on the CEE stock markets - the reduction of the number of companies (January 2012 - December 2016)

\begin{tabular}{|c|c|c|c|c|c|}
\hline $\begin{array}{c}\text { Stock } \\
\text { Ex- } \\
\text { change }\end{array}$ & Index & $\begin{array}{c}\text { Market } \\
\text { Cap. EUR } \\
\text { billion, } \\
\text { Dec } 2016\end{array}$ & $\begin{array}{l}\text { The initial } \\
\text { number of } \\
\text { companies }\end{array}$ & $\begin{array}{l}\text { The number of com- } \\
\text { panies after the re- } \\
\text { duction due to a stock } \\
\text { illiquidity } \\
\text { (<10\% zeros in daily } \\
\text { volume) }\end{array}$ & $\begin{array}{l}\text { The number of com- } \\
\text { panies after the re- } \\
\text { duction due to a stock } \\
\text { illiquidity } \\
(\approx 30 \% \text { zeros in daily } \\
\text { volume) }\end{array}$ \\
\hline PSE & PX & 22.19 & 23 & 10 & 10 \\
\hline BSE & BUX & 21.27 & 41 & 13 & 18 \\
\hline BSSE & SAX & 5.28 & 71 & 0 & 3 \\
\hline LJSE & $\begin{array}{l}\text { SBI- } \\
\text { TOP }\end{array}$ & 5.00 & 37 & 6 & 10 \\
\hline $\begin{array}{l}\text { NASDAQ } \\
\text { Vilnius }\end{array}$ & OMXV & 3.50 & 34 & 7 & 15 \\
\hline $\begin{array}{l}\text { NASDAQ } \\
\text { Tallinn }\end{array}$ & OMXT & 2.29 & 17 & 8 & 12 \\
\hline $\begin{array}{c}\text { NASDAQ } \\
\text { Riga }\end{array}$ & OMXR & 0.80 & 32 & 3 & 7 \\
\hline
\end{tabular}

Note: The fourth column presents the number of all companies listed on each stock exchange. The fifth column reports the number of companies that exhibited less than 125 zeros in daily volume, which constituted about $10 \%$ of all trading days. The last column contains final number of companies (less than 373 zeros in daily volume, which constituted about $30 \%$ of all trading days during the whole sample period).

Table 2 reports brief information about the reduction of the number of companies on the investigated markets that was caused by serious non-trading problems. The CEE stock exchanges are presented in order of decreasing value of the market index capitalization (in EUR billion) at the end of 2016. For comparison, the WIG20 index market capitalization at the end of December 2016 was equal to 130.99 (EUR billion). The WIG20 index consists of 20 major and most liquid companies in the Warsaw Stock Exchange Main List. Therefore, as mentioned above, the WSE is not included in the study because it is not a small stock market. 
As one can observe in Table 2, the number of zeros in daily volume was tremendously high for the BSSE-traded companies. The total number of stocks on the BSSE was equal to 71, while only 3 out of them met basic condition. Finally, 10 (Prague), 18 (Budapest), 3 (Bratislava), 10 (Ljubljana), 15 (Vilnius), 12 (Tallinn), and 7 (Riga) companies were contained in the data set.

Table 3 presents information about all companies in an alphabetical order according to the company's full name.

Table 3. Companies contained in the database (January 2012 - December 2016)

\begin{tabular}{|c|c|c|}
\hline & Stock exchange & Companies \\
\hline 1 & $\begin{array}{l}\text { Prague Stock Exchange } \\
\text { (the Czech Republic) }\end{array}$ & $\begin{array}{c}\text { CETV, CEZ, FOREG, KOMB, PEGAS, RBAG, TABAK, } \\
\text { TELEC, UNIPE, VIG }\end{array}$ \\
\hline 2 & $\begin{array}{l}\text { Budapest Stock Ex- } \\
\text { change (Hungary) }\end{array}$ & $\begin{array}{l}\text { ANY, APPENINN, PANNONIA, ELMU, EMASZ, ESTMEDIA, } \\
\text { FHB, GSPARK, MTELEKOM, MOL, NUTEX, OPIMUS, OTP, } \\
\text { PANNERGY, PLOTINUS, RABA, RICHT, ZWACK }\end{array}$ \\
\hline 3 & $\begin{array}{l}\text { Bratislava Stock Ex- } \\
\text { change (Slovakia) }\end{array}$ & SLN1, TMR, VUB \\
\hline 4 & $\begin{array}{l}\text { Ljubljana Stock Exchange } \\
\text { (Slovenia) }\end{array}$ & $\begin{array}{c}\text { CICG, GRVG, IEKG, KRKG, LKPG, MELR, PETG, POSR, } \\
\text { TLSG, ZVTG }\end{array}$ \\
\hline 5 & $\begin{array}{l}\text { NASDAQ Vilnius } \\
\text { (Lithuania) }\end{array}$ & $\begin{array}{c}\text { AVG1L, APG1L, GRG1L, KNF1L, LNR1L, LNA1L, LGD1L, } \\
\text { PTR1L, PZV1L, RSU1L, SAB1L, TEO1L, VLP1L, VBL1L, } \\
\text { ZMP1L }\end{array}$ \\
\hline 6 & $\begin{array}{l}\text { NASDAQ Tallinn (Esto- } \\
\text { nia) }\end{array}$ & $\begin{array}{c}\text { ARC1T, MRK1T, TVEAT, BLT1T, EEG1T, HAE1T, NCN1T, } \\
\text { OEG1T, PRF1T, SFG1T, TAL1T, TKM1T }\end{array}$ \\
\hline 7 & NASDAQ Riga (Latvia) & GRD1R, BAL1R, GZE1R, LSC1R, OLF1R, SAF1R, VSS1R \\
\hline
\end{tabular}

Note: The companies are presented in an alphabetical order according to the company's full name.

\section{Some Empirical Results of Commonality in Liquidity on the CEE Stock Markets}

In the first step, we detected with the ADF-GLS test (Elliott et al., 1996) or ADF test (Dickey and Fuller, 1981) whether the analysed daily time series are stationary. Using daily data, we utilized a maximum lag equal to five and then removed lags until the last one was statistically significant (Adkins, 2014). We proved that the unit-root hypothesis can be rejected at the 5\% significance level for all time series used in the study.

In order to reduce the effects of possibly spurious outliers, we 'winsorized' the data by using the 1st and 99th percentiles for each time series, e.g. (Korajczyk and Sadka, 2008; Kamara et al., 2008).

In the next step, we employed the OLS method with the HAC covariance matrix estimator to estimate the parameters of the model (1). In total, 75 models for seven stock markets were estimated, comprising 10 models for the PSE, 18 models for the BSE, 3 models for the BSSE, 10 models for the LJSE, 15 
for the NASDAQ Vilnius, 12 for the NASDAQ Tallinn, and 7 for the NASDAQ Riga.

Table 4a. Testing for market-wide commonality in liquidity on four CEE stock markets (the PSE, BSE, BSSE, and LJSE) in the whole sample period from January 2, 2012 to December 30, 2016

\begin{tabular}{|c|c|c|c|c|c|c|c|c|}
\hline & \multicolumn{2}{|c|}{$\begin{array}{c}\text { PSE } \\
\text { (10 models) }\end{array}$} & \multicolumn{2}{|c|}{$\begin{array}{c}\text { BSE } \\
\text { (18 models) }\end{array}$} & \multicolumn{2}{|c|}{$\begin{array}{c}\text { BSSE } \\
\text { (3 models) }\end{array}$} & \multicolumn{2}{|c|}{$\begin{array}{c}\text { LJSE } \\
\text { (10 models) }\end{array}$} \\
\hline & 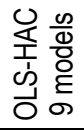 & 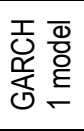 & 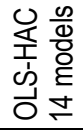 & 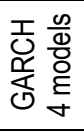 & 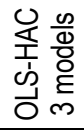 & 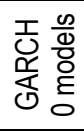 & 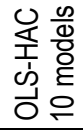 & 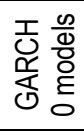 \\
\hline $\begin{array}{c}\text { Intercept } \alpha_{i} \\
\text { significant }\end{array}$ & All & All & All & All & All & - & All & - \\
\hline $\begin{array}{l}\text { Mean } \\
\text { Median }\end{array}$ & \multicolumn{2}{|c|}{2.424} & \multicolumn{2}{|c|}{2.333} & \multicolumn{2}{|c|}{3.843} & \multicolumn{2}{|c|}{5.059} \\
\hline \multicolumn{9}{|l|}{ Concurrent $\beta_{i, 0}$} \\
\hline $\begin{array}{l}\text { Mean } \\
\text { Median }\end{array}$ & \multicolumn{2}{|c|}{0.043} & \multicolumn{2}{|c|}{-0.002} & 0.0002 & 0.0002 & \multicolumn{2}{|c|}{0.023} \\
\hline positive significant & $2 / 9$ & $0 / 1$ & 0/14 & $0 / 4$ & $0 / 3$ & - & $0 / 10$ & - \\
\hline positive insignificant & $3 / 9$ & $0 / 1$ & $5 / 14$ & $0 / 4$ & $3 / 3$ & - & $7 / 10$ & - \\
\hline negative significant & $2 / 9$ & $0 / 1$ & $3 / 14$ & $1 / 4$ & $0 / 3$ & - & $1 / 10$ & - \\
\hline negative insignificant & $2 / 9$ & $1 / 1$ & $6 / 14$ & $3 / 4$ & $0 / 3$ & - & $2 / 10$ & - \\
\hline \multicolumn{9}{|l|}{$\operatorname{Lag} \beta_{i,-1}$} \\
\hline Mean & \multirow{2}{*}{\multicolumn{2}{|c|}{$\begin{array}{l}-0.007 \\
-0.020\end{array}$}} & \multirow{2}{*}{\multicolumn{2}{|c|}{$\begin{array}{l}-0.002 \\
-0.002\end{array}$}} & \multicolumn{2}{|c|}{0.0001} & \multicolumn{2}{|c|}{-0.005} \\
\hline Median & & & & & \multicolumn{2}{|c|}{0} & \multicolumn{2}{|c|}{0.001} \\
\hline positive significant & $0 / 9$ & $0 / 1$ & $1 / 14$ & $0 / 4$ & $0 / 3$ & _- & $0 / 10$ & _- \\
\hline positive insignificant & $4 / 9$ & $0 / 1$ & $1 / 14$ & $3 / 4$ & $1 / 3$ & _- & $5 / 10$ & _- \\
\hline negative significant & $2 / 9$ & $0 / 1$ & $6 / 14$ & $0 / 4$ & $1 / 3$ & - & $2 / 10$ & _- \\
\hline negative insignificant & $3 / 9$ & $1 / 1$ & $6 / 14$ & $1 / 4$ & $1 / 3$ & - & $3 / 10$ & - \\
\hline \multicolumn{9}{|l|}{ Lead $\beta_{i,+1}$} \\
\hline Mean & \multirow{2}{*}{\multicolumn{2}{|c|}{$\begin{array}{l}-0.019 \\
-0.032\end{array}$}} & \multicolumn{2}{|c|}{0.002} & \multicolumn{2}{|c|}{-0.0004} & \multicolumn{2}{|c|}{-0.001} \\
\hline Median & & & & & & & & \\
\hline positive significant & $0 / 9$ & $1 / 1$ & $1 / 14$ & $0 / 4$ & $0 / 3$ & - & $0 / 10$ & - \\
\hline positive insignificant & $2 / 9$ & $0 / 1$ & $6 / 14$ & $1 / 4$ & $1 / 3$ & - & $4 / 10$ & - \\
\hline negative significant & $2 / 9$ & $0 / 1$ & $4 / 14$ & $1 / 4$ & $1 / 3$ & - & $4 / 10$ & - \\
\hline negative insignificant & $5 / 9$ & $0 / 1$ & $3 / 14$ & $2 / 4$ & $1 / 3$ & - & $2 / 10$ & - \\
\hline
\end{tabular}

Note: Notation like in Table 1.

For each stock, daily proportional changes in individual stock liquidity variables were regressed in time-series on the changes of an equally weighted cross-sectional average of the liquidity variable for all stocks in the sample, excluding the dependent variable stock. Empirical results revealed that the OLS-HAC method turned out to be appropriate for the estimation of model (1) in the case of all companies from the BSSE, LJSE, and NASDAQ Riga exchanges. In other cases, the $\operatorname{GARCH}(p, q), p, q=1,2$, models (3) were 
estimated. The number of lags $p, q$ was selected on the basis of the AIC and $\mathrm{SC}$ information criteria.

The summarized cross-sectional estimation results of the models (1) and (3) are presented in Tables $4 a-4 b$. These tables report basic statistics and the proportion of positive significant, positive insignificant, negative significant, and negative insignificant coefficients (at 10\% significance level), for each stock market, separately. The empirical findings are worth comments. The regressions provide weak evidence of commonality in liquidity on the investigated markets because positive and statistically significant coefficients are scarce or not present at all. For example, positive and statistically significant concurrent coefficients constitute 2/10 (PSE), 0/18 (BSE), 0/3 (BSSE), 0/10 (LJSE), 0/15 (NASDAQ Vilnius), 0/12 (NASDAQ Tallinn), and 0/7 (NASDAQ Riga), respectively. The evidence concerning lag and lead coefficients is very similar.

Moreover, the proportions of negative and statistically significant concurrent, lag, and lead coefficients are even greater for all markets, which informs about liquidity co-movements in the opposite direction.

\section{Conclusion}

The main goal of this paper was to explore the existence of commonality in liquidity patterns on seven small CEE emerging stock markets in the Czech Republic, Hungary, Slovakia, Slovenia, Lithuania, Estonia, and Latvia, in the context of serious problems with stock liquidity. Due to the non-trading effect, the data was filtered out, and the reduction of the number of companies on the investigated markets was crucial. The reduction was tremendously high for the BSSE-traded companies. The total number of stocks on the BSSE was equal to 71, while only 3 out of them were contained in the database. The most liquid BSSE-company (VUB) exhibited 295 non-traded days during the whole sample period, which constituted about $24 \%$ of all trading days.

The sample covered a period from January 2, 2012 to December 30, 2016. A modified version of the Amihud (2002) measure was used as daily liquidity proxy for stocks. We followed the research design of Chordia et al. (2000), but we employed the OLS method with the HAC covariance matrix estimation and the GARCH-type models to infer the patterns of intra-market commonality in liquidity on the CEE stock markets. According to the literature, positive and statistically significant slope coefficients in the estimated models are especially desired, as they indicate intra-market co-movements in liquidity in the same direction, and therefore confirm commonality in liquidity. 
Table $4 \mathrm{~b}$. Testing for market-wide commonality in liquidity on three CEE stock markets (the NASDAQ-OMX Group) in the whole sample period from January 2, 2012 to December 30, 2016

\begin{tabular}{|c|c|c|c|c|c|c|}
\hline & \multicolumn{2}{|c|}{$\begin{array}{l}\text { NASDAQ Vilnius } \\
\text { (15 models) }\end{array}$} & \multicolumn{2}{|c|}{$\begin{array}{l}\text { NASDAQ Tallinn } \\
(12 \text { models) }\end{array}$} & \multicolumn{2}{|c|}{$\begin{array}{c}\text { NASDAQ Riga } \\
\text { (7 models) }\end{array}$} \\
\hline & 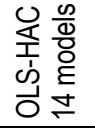 & 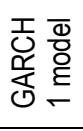 & 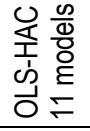 & 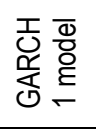 & 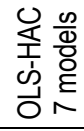 & 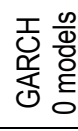 \\
\hline $\begin{array}{l}\text { Intercept } \alpha_{i} \\
\text { significant }\end{array}$ & All & All & All & All & All & - \\
\hline Mean & \multicolumn{2}{|c|}{1.334} & \multicolumn{2}{|c|}{2.078} & \multicolumn{2}{|c|}{2.332} \\
\hline Median & \multicolumn{2}{|c|}{0.996} & \multicolumn{2}{|c|}{2.001} & \multicolumn{2}{|c|}{2.029} \\
\hline Concurrent $\beta_{i, 0}$ & \multirow{3}{*}{\multicolumn{2}{|c|}{$\begin{array}{l}0.003 \\
0\end{array}$}} & \multirow{2}{*}{\multicolumn{2}{|c|}{0.009}} & \multirow{2}{*}{\multicolumn{2}{|c|}{0.009}} \\
\hline Mean & & & & & & \\
\hline Median & & & \multicolumn{2}{|c|}{0.006} & \multicolumn{2}{|c|}{0.001} \\
\hline positive significant & 0/14 & $0 / 1$ & $0 / 11$ & $0 / 1$ & $0 / 7$ & - \\
\hline positive insignificant & $9 / 14$ & $1 / 1$ & $6 / 11$ & $1 / 1$ & $4 / 7$ & - \\
\hline negative significant & $1 / 14$ & $0 / 1$ & $2 / 11$ & $0 / 1$ & $1 / 7$ & - \\
\hline negative insignificant & $4 / 14$ & $0 / 1$ & $3 / 11$ & $0 / 1$ & $2 / 7$ & - \\
\hline \multicolumn{7}{|l|}{$\operatorname{Lag} \beta_{i,-1}$} \\
\hline Mean & \multirow{2}{*}{\multicolumn{2}{|c|}{$\begin{array}{l}-0.007 \\
-0.009\end{array}$}} & \multirow{2}{*}{\multicolumn{2}{|c|}{$\begin{array}{l}-0.012 \\
-0.011\end{array}$}} & \multirow{2}{*}{\multicolumn{2}{|c|}{$\begin{array}{l}-0.006 \\
-0.007\end{array}$}} \\
\hline Median & & & & & & \\
\hline positive significant & 0/14 & $0 / 1$ & $0 / 11$ & $0 / 1$ & $0 / 7$ & - \\
\hline positive insignificant & $3 / 14$ & $0 / 1$ & $2 / 11$ & $0 / 1$ & $3 / 7$ & - \\
\hline negative significant & $5 / 14$ & $0 / 1$ & $5 / 11$ & $0 / 1$ & $2 / 7$ & - \\
\hline negative insignificant & $6 / 14$ & $1 / 1$ & $4 / 11$ & $1 / 1$ & $2 / 7$ & - \\
\hline \multicolumn{7}{|l|}{ Lead $\beta_{i+1}$} \\
\hline Mean & \multicolumn{2}{|c|}{0.000} & \multicolumn{2}{|c|}{-0.012} & \multicolumn{2}{|c|}{-0.010} \\
\hline Median & \multicolumn{2}{|c|}{0.004} & \multicolumn{2}{|c|}{-0.009} & \multicolumn{2}{|c|}{-0.015} \\
\hline positive significant & $0 / 14$ & $0 / 1$ & $0 / 11$ & $0 / 1$ & $0 / 7$ & - \\
\hline positive insignificant & $9 / 14$ & $0 / 1$ & $1 / 11$ & $0 / 1$ & $2 / 7$ & - \\
\hline negative significant & $2 / 14$ & $0 / 1$ & $3 / 11$ & $0 / 1$ & $1 / 7$ & - \\
\hline negative insignificant & $3 / 14$ & $1 / 1$ & $7 / 11$ & $1 / 1$ & $4 / 7$ & - \\
\hline
\end{tabular}

Note: Notation like in Table 1.

In general, our estimation results do not support the existence of commonality in liquidity effects on all investigated markets, because positive and statistically significant coefficients are scarce or not present at all. The results are consistent with the literature regarding other emerging small markets in the world.

A possible direction for further investigation could be to study marketwide co-movements in liquidity on the CEE stock exchanges by utilizing different daily liquidity proxy. Moreover, another possible direction could be to identify components of liquidity on the CEE stock markets by using methods based on principal component analysis. 


\section{References}

Adkins, L.C. (2014), Using Gretl for Principles of Econometrics. 4th Ed.Version 1.041.

Amihud, Y. (2002), Illiquidity and Stock Returns: Cross-Section and Time-Series Effects, Journal of Financial Markets, 5(1), 31-56, DOI: http://dx.doi.org/10.1016/S1386-4181(01)00024-6.

Bai, M., Qin, Y. (2015), Commonality in Liquidity in Emerging Markets: Another Supply-Side Explanation, International Review of Economics \& Finance, 39, 90-106, DOI: http://dx.doi.org/10.1016/j.iref.2015.06.005.

Bekaert, G., Harvey, C.R., Lundblad, C. (2007), Liquidity and Expected Returns: Lessons from Emerging Markets, Review of Financial Studies, 20(6), 1783-1831, DOI: http://dx.doi.org/10.1093/rfs/hhm030.

Będowska-Sójka, B. (2018), The Coherence of Liquidity Measures. The Evidence from the Emerging Market, Finance Research Letters, 27, 118-123, DOI: https://doi.org/10.1016/j.frl.2018.02.014.

Bollerslev, T., Wooldridge, J.M. (1992), Quasi-Maximum Likelihood Estimation and Inference in Dynamic Models with Time-Varying Covariances, Econometric Reviews, 11, 143-179, DOI: http://dx.doi.org/10.1080/07474939208800229.

Brockman, P., Chung, D.Y. (2006), Index Inclusion and Commonality in Liquidity: Evidence from the Stock Exchange of Hong Kong, International Review of Financial Analysis, 15(4-5), 291-305, DOI: http://dx.doi.org/10.1016/j.irfa.2005.09.003.

Brockman, P., Chung, D.Y., Perignon, C. (2009), Commonality in Liquidity: A Global Perspective, Journal of Financial and Quantitative Analysis, 44(4), 851-882, DOI: http://dx.doi.org/10.1017/S0022109009990123.

Campbell, J.Y., Lo, A.W., MacKinlay, A.C. (1997), The Econometrics of Financial Markets, Princeton University Press, New Jersey.

Chordia, T., Roll, R., Subrahmanyam, A. (2000), Commonality in Liquidity, Journal of Financial Economics, 56, 3-28, DOI: http://dx.doi.org/10.1016/S0304-405X(99)00057-4.

Dickey, D.A., Fuller, W.A. (1981), Likelihood Ratio Statistics for Autoregressive Time Series with a Unit Root, Econometrica, 49(4), 1057-1072, DOI: http://dx.doi.org/10.2307/1912517.

Dimson, E. (1979), Risk Measurement when Shares are Subject to Infrequent Trading, Journal of Financial Economics, 7, 197-226, DOI: http://dx.doi.org/10.1016/0304-405X(79)90013-8.

Elliott, G., Rothenberg, T.J., Stock, J.H. (1996), Efficient Tests for an Autoregressive Unit Root, Econometrica, 64(4), 813-836, DOI: http://dx.doi.org/10.2307/2171846.

Engle, R.F. (1982), Autoregressive Conditional Heteroscedasticity with Estimates of the Variance of United Kingdom Inflations, Econometrica, 50, 987-1007, DOI: http://dx.doi.org/10.2307/1912773.

Fabre, J., Frino, A. (2004), Commonality in Liquidity: Evidence from the Australian Stock Exchange, Accounting and Finance, 44, 357-368, DOI: http://dx.doi.org/10.1111/j.1467-629x.2004.00117.x.

Fong, K.Y.L., Holden, C.W., Trzcinka, C. (2017), What are the Best Liquidity Proxies for Global Research?, Review of Finance, 21, 1355-1401, DOI: http://dx.doi.org/10.1093/rof/rfx003.

Foran, J., Hutchinson, M.C., O’Sullivan, N. (2015), Liquidity Commonality and Pricing in UK Equities, Research in International Business and Finance, 34, 281-293, DOI: http://dx.doi.org/10.1016/j.ribaf.2015.02.006. 
Goyenko, R.Y., Holden, C.W., Trzcinka, C.A. (2009), Do Liquidity Measures Measure Liquidity?, Journal of Financial Economics, 92, 153-181, DOI: $\mathrm{http} / / / \mathrm{dx}$.doi.org/10.1016/j.jfineco.2008.06.002.

Hamilton, J.D. (2008), Macroeconomics and ARCH. Working Paper 14151 NBER Working Paper Series, Cambridge.

Kamara, A., Lou, X., Sadka, R. (2008), The Divergence of Liquidity Commonality in the CrossSection of Stocks, Journal of Financial Economics, 89(3), 444-466, DOI: http://dx.doi.org/10.1016/j.jfineco.2007.10.004.

Kang, W., Zhang, H. (2013), Limit Order Book and Commonality in Liquidity, Financial Review, 48(1), 97-122, DOI: http://dx.doi.org/10.1111/j.1540-6288.2012.00348.x.

Karolyi, G.A., Lee, K.-H., van Dijk, M.A. (2012), Understanding Commonality in Liquidity Around the World, Journal of Financial Economics, 105(1), 82-112, DOI: http://dx.doi.org/10.1016/i.jfineco.2011.12.008.

Kempf, A., Mayston, D. (2008), Liquidity Commonality Beyond Best Prices, Journal of Financial Research, 31(1), 25-40,

DOI: http://dx.doi.org/10.1111/j.1475-6803.2008.00230.x.

Korajczyk, R., Sadka, R. (2008), Pricing the Commonality Across Alternative Measures of Liquidity, Journal of Financial Economics, 87(1), 45-72, DOI: http://dx.doi.org/10.1016/j.jfineco.2006.12.003.

Miralles Marcelo, J.L., Miralles Quirós, M., Oliveira, C. (2015), Systematic Liquidity: Commonality and Intertemporal Variation in the Portuguese Stock Market, Cuadernos de Gestion, 15(2), 39-64. DOI: http://dx.doi.org/10.5295/cdg.140472mm.

Narayan, P.K., Zhang, Z., Zheng, X. (2015), Some Hypotheses on Commonality in Liquidity: New Evidence from the Chinese Stock Market, Emerging Markets Finance \& Trade, 51, 915-944, DOI: http://dx.doi.org/10.1080/1540496X.2015.1061799.

Newey, W.K., West, K.D. (1987), A Simple, Positive Semi-Define, Heteroskesticity and Autocorrelation Consistent Covariance Matrix, Econometrica, 55(3), 703-708, DOI: http://dx.doi.org/10.2307/1913610.

Nowak, S., Olbryś, J. (2016), Direct Evidence of Non-Trading on the Warsaw Stock Exchange, Research Papers of Wroclaw University of Economics, 428, 184-194.

Olbryś, J. (2014), Is Illiquidity Risk Priced? The Case of the Polish Medium-Size Emerging Stock Market, Bank i Kredyt, 45(6), 513-536.

Olbryś, J. (2018), Intra-Market Commonality in Liquidity. New Evidence from the Polish Emerging Stock Market, SSEM EuroConference 2018: Emerging Market Economies, June 7-8, 2018, Lodz, Poland.

Olbryś, J., Mursztyn, M. (2018), On Some Characteristics of Liquidity Proxy Time Series. Evidence from the Polish Stock Market, in: Tsounis N., Vlachvei A. (eds) Advances in Time Series Data Methods in Applied Economic Research. Springer Proceedings in Business and Economics, Springer, Cham, 177-189, DOI: http://dx.doi.org/10.1007/978-3-030-02194-8 13.

Pukthuanthong-Le, K., Visaltanachoti, N. (2009), Commonality in Liquidity: Evidence from the Stock Exchange of Thailand, Pacific-Basin Finance Journal, 17(1), 80-99, DOI: http://dx.doi.org/10.1016/j.pacfin.2007.12.004.

Sensoy, A. (2016), Commonality in Liquidity: Effects of Monetary Policy and Macroeconomic Announcements., Finance Research Letters, 16, 125-131, DOI: $\mathrm{http}: / / \mathrm{dx}$.doi.org/10.1016/i.frl.2015.10.021.

Syamala, S.R., Wadhwa, K., Goyal, A. (2017), Determinants of Commonality in Liquidity: Evidence from an Order-Driven Emerging Market, North American Journal of Economics and Finance, 42, 38-52, DOI: http://dx.doi.org/10.1016/j.najef.2017.07.003.

Tsay, R.S. (2010), Analysis of Financial Time Series, John Wiley, New York. 
Wang, J. (2013), Liquidity Commonality Among Asian Equity Markets, Pacific-Basin Finance Journal, 21(1), 1209-1231,

DOI: http://dx.doi.org/10.1016/j.pacfin.2012.06.003.

\section{Wpływ problem braku transakcji na badanie wspólności w płynności na małych rynkach giełdowych}

Z a rys tre ści. Artykuł przedstawia badanie wspólności w płynności na siedmiu małych giełdach Europy Środkowo-Wschodniej w kontekście problemu braku transakcji, czyli bardzo dużej liczby dni z zerowym wolumenem. Przeprowadzono konieczną redukcję niepłynnych spółek na badanych rynkach, co spowodowało znaczny spadek liczby firm uczestniczących w badaniu. Jako estymator dziennej płynności zastosowano zmodyfikowaną miarę Amihuda. W celu identyfikacji wzorców w płynności wykorzystano modele OLS-HAC oraz GARCH. Nie stwierdzono efektu wspólności w płynności na żadnym z badanych rynków giełdowych.

S łow a k l u c zow e: Europa Środkowo-Wschodnia; wspólność w płynności; GARCH; $\mathrm{HAC}$; problem braku transakcji. 